\title{
Metabolic changes of salicylic acid-elicited Catharanthus roseus cell suspension cultures monitored by NMR-based metabolomics
}

\author{
Natali Rianika Mustafa · Hye Kyong Kim • \\ Young Hae Choi · Robert Verpoorte
}

Received: 23 July 2009/ Accepted: 30 July 2009/Published online: 22 August 2009

(C) The Author(s) 2009. This article is published with open access at Springerlink.com

\begin{abstract}
The effect of salicylic acid (SA) on the metabolic profile of Catharanthus roseus suspension cells throughout a time course $(0,6,12,24,48$ and $72 \mathrm{~h}$ after treatment) was investigated using NMR spectroscopy and multivariate data analysis. When compared to control cell lines, SA-treated cells showed a high level of sugars (glucose and sucrose) up to $48 \mathrm{~h}$ after treatment, followed by a dynamic change in amino acids, phenylpropanoids, and tryptamine. Additionally, one compound-2,5-dihydroxybenzoic-5- $O$ glucoside-was detected solely in SA-treated cells.
\end{abstract}

Keywords Catharanthus roseus .

Cell suspension cultures · Elicitation ·

Nuclear magnetic resonance spectroscopy-based metabolomics $\cdot$ Salicylic acid

\section{Introduction}

Catharanthus roseus is a terpenoid indole-alkaloid (TIA) producing plant. More than 100 TIAs have been identified in this species, including the anti-tumor agents vincristine and vinblastine (dimeric) and the

N. R. Mustafa · H. K. Kim $(\square) \cdot$ Y. H. Choi ·

R. Verpoorte

Division of Pharmacognosy, Section Metabolomics,

Institute of Biology, Leiden University, Einsteinweg 55,

2333, CC, Leiden, The Netherlands

e-mail: h.k.kim@chem.leidenuniv.nl anti-hypertensive ajmalicine. Other simple phenolic metabolites $(\mathrm{C} 6 \mathrm{C} 1)$ probably involved in the interaction of this plant species with its environment have also been detected (reviewed by Mustafa and Verpoorte 2007). Among these, salicylic acid (SA)—a compound derived from chorismate, the end-product of the shikimate pathway-functions as a signal compound in plants to induce a defense system known as systemic acquired resistance (SAR), a response to a pathogenic attack (Ryals et al. 1996). However, chorismate is the substrate of five different enzymes involved in the production of various secondary metabolites (reviewed by Mustafa and Verpoorte 2005) so that the possibility of distinguishing SA-dependent and independent pathways would contribute to gain more insight in SAR related secondary metabolite production. The level of SA increases in plants attacked by pathogens, e.g., tobacco mosaic virus (Verberne et al. 2000) or Pythium aphanidermatum (Mustafa et al. 2009). Elicitation with Pythium extract also produced an increase of 2,3-dihydroxybenzoic acid (2,3-DHBA; Moreno et al. 1994; Budi Muljono et al. 2002) and tryptamine (Moreno et al. 1996) in C. roseus suspension cells. However, Pythium extract is a mixture of compounds, which may activate different parts of the SAR pathways employing diverse signaling compounds. In order to identify exclusively SA affected metabolites, NMR spectroscopy in combination with multivariate data analysis, a powerful tool for plant metabolite studies, was used. There are numerous successful examples of its application, such 
as the discrimination between healthy and phytoplasma infected C. roseus leaves (Choi et al. 2004), the metabolic profiling of Passiflora garckei (Fraccaroli et al. 2008) and the differentiation between Tabernaemontana divaricata cell suspension cultures before and after cryopreservation (Suhartono et al. 2005).

In this study, we analyzed the effect of SA on the metabolite profile of $C$. roseus cell suspension culture using NMR combined with multivariate data analysis such as principal component analysis (PCA) and partial least square-discriminant analysis (PLS-DA).

\section{Materials and methods}

Plant cell cultures

Catharanthus roseus line A12A2 was grown in Murashige and Skoog (1962; M\&S) liquid medium without growth hormone and supplemented with $2 \%$ $(\mathrm{w} / \mathrm{v})$ glucose as a carbon source. The cells were grown in $250 \mathrm{ml}$ Erlenmeyer flasks containing $100 \mathrm{ml}$ medium, cultivated at $24-25^{\circ} \mathrm{C}$ under continuous light (500-1500 lux) on a shaker at $100 \mathrm{rpm}$, and subcultured every week by adding the same amount of fresh medium into the cell cultures for maintenance. For the experiment, the suspension cells were subcultured into $100 \mathrm{ml}$ Erlenmeyer flasks (each containing $50 \mathrm{ml}$ medium) in the same cultivation conditions for 5 days prior to elicitation.

\section{Elicitation and harvesting cells}

Elicitation with salicylic acid (SA) was achieved by adding $50 \mu \mathrm{l}$ of a previously $0.2 \mu \mathrm{m}$-membrane filtered solution of $0.5 \mathrm{M}$ sodium salicylate to a $100 \mathrm{ml}$ flask containing $50 \mathrm{ml}$ cell suspension culture. As a control, $50 \mu \mathrm{l}$ sterilized-water was added to $50 \mathrm{ml}$ cell suspension culture. The elicited cells as well as the control cells were harvested at time 0,6 , $12,24,48$ and $72 \mathrm{~h}$ after the addition of the sodium salicylate or the sterile water. Experiments were performed by triplicate both for the elicited cells and the control cells. In the harvesting step, the cells from each flask were rinsed twice with $100 \mathrm{ml}$ of deionized water, vacuum filtered using a P2 glass-filter, transferred to a $10 \mathrm{ml}$ plastic tube, weighed and stored in $-80^{\circ} \mathrm{C}$. These frozen-cells were freeze-dried in $48 \mathrm{~h}$.

\section{Extraction}

Freeze-dried cells $(50 \mathrm{mg})$ from each flask were placed in a $2 \mathrm{ml}$ micro-tube and extracted with $750 \mu \mathrm{CH}_{3} \mathrm{OH}-d_{4}$ and $750 \mu \mathrm{KH}_{2} \mathrm{PO}_{4}-d_{2}$ buffer in $\mathrm{D}_{2} \mathrm{O}(\mathrm{pH}$ 6.0). The mixture was vortexed $(2,500 \mathrm{rpm}$, $1 \mathrm{~min})$ using an electronic vortex mixer followed by sonication $(20 \mathrm{~min})$ in an ultrasonic bath and centrifugation $(10,000 \times g, 15 \mathrm{~min})$. The supernatant was transferred into a $5 \mathrm{~mm}$ NMR tube for NMR measurements.

NMR measurements

${ }^{1} \mathrm{H}-\mathrm{NMR}$ and J-resolved spectra were recorded at $25^{\circ} \mathrm{C}$ on a $400 \mathrm{MHz}$ Bruker AV-400 spectrometer operating at proton NMR frequency of $400.13 \mathrm{MHz}$. $\mathrm{CH}_{3} \mathrm{OH}-d_{4}$ was used as an internal lock. Each spectrum consisted of 128 scans requiring $10 \mathrm{~min}$ acquisition time with the following parameters: $0.25 \mathrm{~Hz} /$ point, pulse width $(\mathrm{PW})=45^{\circ}(6.6 \mu \mathrm{s})$, and relaxation delay $(\mathrm{Dl})=$ $2.0 \mathrm{~s}$. A presaturation sequence was used to suppress the residual water signal with low power selective irradiation at the water frequency during the recycle delay. FIDs were Fourier transformed with $\mathrm{LB}=$ $0.3 \mathrm{~Hz}$ and the spectra were zero-filled to $32 \mathrm{~K}$ points. The window functions were optimized for the analysis. The resulting spectra were manually phased and baseline corrected, and calibrated to TMSP at $0.0 \mathrm{ppm}$, always using XWIN NMR (version 3.5, Bruker). Two dimensional J-resolved ${ }^{1} \mathrm{H}-\mathrm{NMR}$ spectra were acquired using 8 scans per 32 increments that were collected into $16 \mathrm{~K}$ data points, using spectral widths of $5.208 \mathrm{KHz}$ in F2 (chemical shift axis) and $50 \mathrm{~Hz}$ in F1 (spin-spin coupling constant axis). A 1 s relaxation delay was employed, giving a total acquisition time of $14.52 \mathrm{~min}$. Datasets were zero-filled to 512 points in F1 and both dimensions were multiplied by sine-bell functions prior to double complex FT. J-resolved spectra tilted by $45^{\circ}$ were symmetrized about F1 and then calibrated, always using XWIN NMR (version 3.5 Bruker). Data were exported as the $1 \mathrm{D}$ projection (F2 axis) of the 2D J-resolved spectra.

Data analysis

The ${ }^{1} \mathrm{H}$-NMR and $\mathrm{F}_{2}$-projected J-resolved spectra were automatically reduced to ASCII files using AMIX (v. 3.7, Bruker Biospin). Spectral intensities 
were scaled to TMSP and reduced to integrated regions of equal width $(0.04 \mathrm{ppm})$ corresponding to the region of $\delta-0.4$ to $\delta 10$. Principal component analyses (PCA) partial least square-discriminant analysis (PLS-DA) were performed with the SIMCA-P software (v. 12.0, Umetrics, Umeå, Sweden).

\section{Results and discussion}

NMR spectra were elucidated with the help of NMR spectra of reference compounds and two dimensional NMR techniques including J-resolved, COSY, HSQC, and HMBC (Table 1).

In general, ${ }^{1} \mathrm{H}$-NMR spectroscopy has been used as a platform for NMR-based metabolomics. Although the use of ${ }^{1} \mathrm{H}-\mathrm{NMR}$ has many advantages in terms of short measuring times and easy quantitation, overlapping ${ }^{1} \mathrm{H}-\mathrm{NMR}$ signals produce complex spectra that hinder their subsequent multivariate data analysis. This has been overcome by the use of projected J-resolved spectrum in which all the split signals become singlets (Viant 2003; Choi et al. 2006). This technique was thus applied in this case and the projected J-resolved spectra of control- and

Table 1 Characteristic chemical shifts ( $\delta$ in ppm) and coupling constants $(J)$ of some compounds detected in the ${ }^{1} \mathrm{H}$ NMR and J-resolved ${ }^{1} \mathrm{H}-\mathrm{NMR}$ spectra $\left(\mathrm{CH}_{3} \mathrm{OH}-d_{4}-\mathrm{KH}_{2} \mathrm{PO}_{4}\right.$ in
SA-treated cells harvested at $0,6,12,24,48$ and $72 \mathrm{~h}$ after treatment were analyzed by principal component analysis (PCA; Fig. 1).

The score-plot of PCA is shown in Fig. 2a. The combination of PC1 and PC2 allowed the differentiation of the cell line samples based on SA-treatment and time points. While PC1 affected the age of the cell lines (older samples moved to negative PC1 both in control and treated samples), PC2 separated the treated groups from the control groups, for which the elicited groups gave a positive effect of PC2 as compared to control groups. In particular, the cell lines harvested $48 \mathrm{~h}$ after treatment were clearly distinguished from the corresponding control cell lines. Control groups corresponding to the $0-24 \mathrm{~h}$ interval were not differentiated by $\mathrm{PC} 1$, whereas the rest of the control groups (48-72 h) resulted in a negative effect to PC1. The negative effect observed for $48 \mathrm{~h}$ and $72 \mathrm{~h}$ of control groups are related to changes in the growth stage of the cells (age).

Among the elicited groups, initial time $(0 \mathrm{~h})$ treated cells had the highest positive effect on PC1 which decreased with time, indicating the occurrence of an immediate change, such as $\mathrm{pH}$, oxidative-burst or glucosidase activity after elicitation as compared to the

$\mathrm{D}_{2} \mathrm{O}, \mathrm{pH}$ 6.0, 1:1) of control- and SA-treated cells of Catharanthus roseus suspension culture

\begin{tabular}{ll}
\hline Compound & Chemical shift $(\mathrm{ppm})$ and coupling constant $(\mathrm{Hz})$ \\
\hline Leucine & $\delta 0.97(d, J=6.5 \mathrm{~Hz}) ; \delta 0.98(d, J=6.7 \mathrm{~Hz})$ \\
Isoleucine & $\delta 0.95(t, J=7.5 \mathrm{~Hz}) ; \delta 1.02(d, J=6.8 \mathrm{~Hz})$ \\
Valine & $\delta 1.00(\mathrm{H}-\gamma, d, J=7.0 \mathrm{~Hz}) ; \delta 1.05\left(\mathrm{H}-\gamma^{\prime}, d, J=7.0 \mathrm{~Hz}\right)$ \\
Threonine & $\delta 1.33(\mathrm{H}-\gamma, d, J=6.6 \mathrm{~Hz})$ \\
Alanine & $\delta 1.48(\mathrm{H}-\beta, d, J=7.2 \mathrm{~Hz})$ \\
Glutamic acid & $\delta 2.46(\mathrm{H}-\gamma, m), \delta 2.13(\mathrm{H}-\beta, m)$ \\
Aspartic acid & $\delta 2.82\left(\mathrm{H}-, d d, J_{1}=8.1 \mathrm{~Hz}, J_{2}=17.0 \mathrm{~Hz}\right) ;$ \\
& $\delta 2.95\left(\mathrm{H}-, d d, J_{1}=3.8 \mathrm{~Hz}, J_{2}=16.8 \mathrm{~Hz}\right) ;$ \\
& $\delta 3.94\left(\mathrm{H}-, d d, J_{1}=3.8 \mathrm{~Hz}, J_{2}=8.4 \mathrm{~Hz}\right)$ \\
Glucose & $\delta 5.18(\alpha-\mathrm{form}, \mathrm{H}-1, d, J=3.8 \mathrm{~Hz}), \delta 4.58(\beta-\mathrm{form}, \mathrm{H}-1, d, J=7.8 \mathrm{~Hz})$, \\
Sucrose & $\delta 5.40(\mathrm{H}-1, d, J=3.8 \mathrm{~Hz}) ; \delta 4.17\left(\mathrm{H}-1{ }^{\prime}, d, J=8.6 \mathrm{~Hz}\right)$ \\
Fumaric acid & $\delta 6.54(s)$ \\
Phenylalanine & $\delta 7.36(m)$ \\
Salicylic acid (2-hydroxybenzoic acid) & $\delta 6.88(\mathrm{H}-3, d, J=8 \mathrm{~Hz}) ; \delta 6.90(\mathrm{H}-5, t, J=7.5 \mathrm{~Hz}) ;$ \\
& $\delta 7.37(\mathrm{H}-4, t, J=7.5 \mathrm{~Hz}) ; \delta 7.81(\mathrm{H}-6, d, J=8 \mathrm{~Hz})$ \\
Gentisic acid glucoside & $\delta 6.83(\mathrm{H}-3, d, J=9 \mathrm{~Hz}) ; \delta 7.17\left(\mathrm{H}-4, d d, J_{l}=9 \mathrm{~Hz}\right.$, \\
$(2,5-$ dihydroxybenzoic acid glucoside $)$ & $\left.J_{2}=3 \mathrm{~Hz}\right) ; \delta 7.56(\mathrm{H}-6, d, J=3 \mathrm{~Hz}) ; \delta 4.88\left(\mathrm{H}-1{ }^{\prime}, d, J=7.5 \mathrm{~Hz}\right)$ \\
\hline
\end{tabular}

$s$ Singlet, $d$ doublet, $t$ triplet, $m$ multiplet 
Fig. $1{ }^{1} \mathrm{H}$ NMR (a), two dimensional J-resolved (b), and projected one dimensional J-resolved (c) spectra of control

Catharanthus roseus cell line in the range of $\delta 6.00-\delta 8.00$
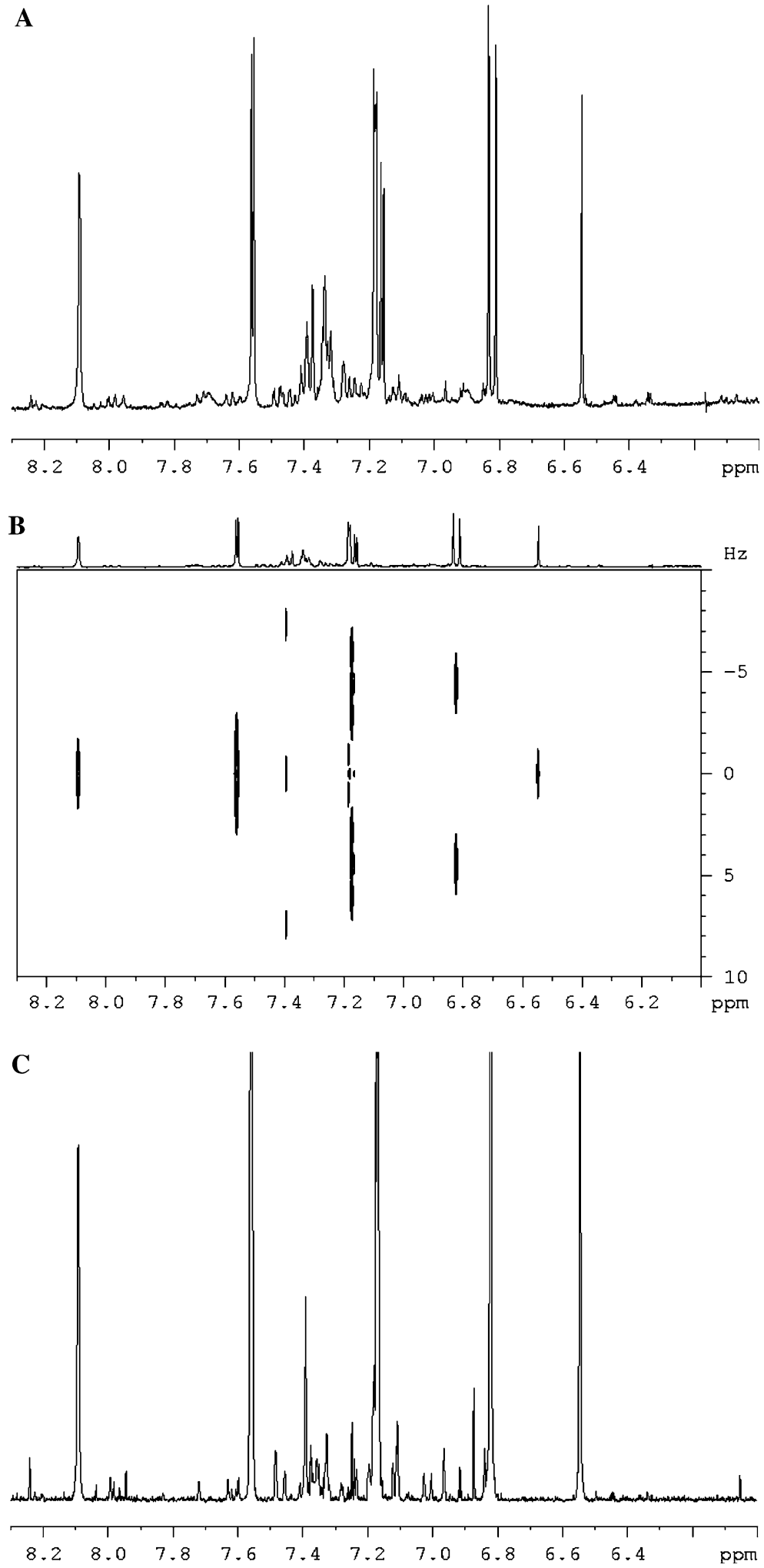


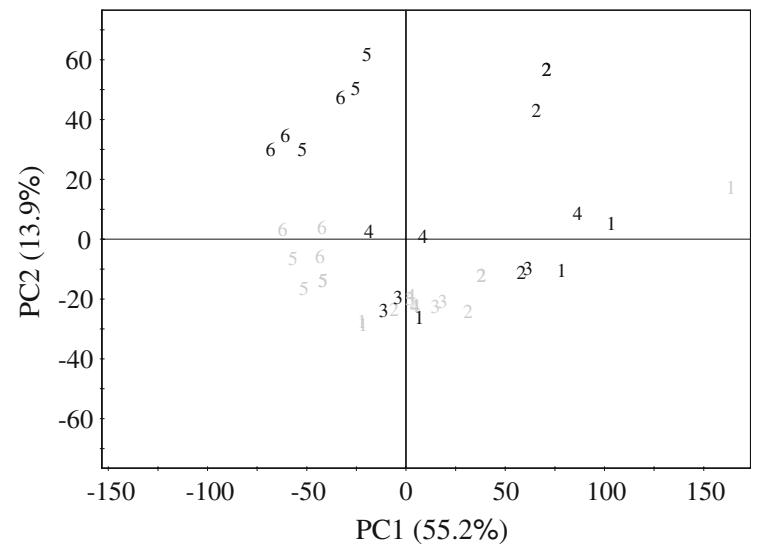

Fig. 2 Score plot of principal component analysis of projected one dimensional J-resolved data of Catharanthus roseus cells. Grey: control cells, Black: Salicylate treated cells, 10 h, 26 h, $312 \mathrm{~h}, 424 \mathrm{~h}, 548 \mathrm{~h}, 672 \mathrm{~h}$ after treatment

control groups $(0,12$ and $24 \mathrm{~h})$, after which it normalized again ( $24 \mathrm{~h}$ after elicitation) to produce a second change in the longer term $(48-72 \mathrm{~h}$ after elicitation), probably dependent on gene-induction. Either SA or JA (jasmonic acid) or other signal compounds are capable of inducing such a change. The change in the metabolic profile observed in this study followed a pattern comparable to that observed in gene-expression or enzyme activity in $C$. roseus suspension cultures treated by JA or Pythium extract reported by other groups (van der Fits and Memelink 2001; Pasquali et al. 1992; Moreno et al. 1996). Van der Fits and Memelink (2001) showed that elicitation of $C$. roseus cells with methyl jasmonate (MeJA) rapidly induced a regulator gene ORCA3 already within $0-2 \mathrm{~h}$ peaking at $0.5 \mathrm{~h}$, whilst the mRNA of the structural genes, e.g., TDC and STR responsible for tryptophan decarboxylase (TDC) and strictosidine synthase (STR) were strongly induced later, 2-8 h after elicitation with a maximum at $8 \mathrm{~h}$. Pasquali et al. (1992) also reported that $C$. roseus TDC and STR were induced $8 \mathrm{~h}$ after elicitation with extracts from yeast or P. aphanidermatum and Moreno et al. (1996) showed that an increase in anthranilate synthase (AS) activity from 2 to around 8 nkatl $^{-1}$ occurred more than $10 \mathrm{~h}$ after elicitation, whereas TDC activity increased from around 20 to 90 nkatl $^{-1}$ between 20 and $30 \mathrm{~h}$ after elicitation with Pythium extract. Strictosidine synthase and strictosidine- $\beta$ glucosidase activities were slightly increased compared to control cells. Budi Muljono et al. (2002) observed a metabolic change through time in C. roseus cells elicited by Pythium extract, noting that the largest increase of the level of endogenous SA in the cells occurred $8 \mathrm{~h}$ after elicitation, whilst the highest increase of the level of 2,3-DHBA in the cells was found $20 \mathrm{~h}$ after elicitation and $24 \mathrm{~h}$ after elicitation in the medium.

All these previous results prove that different phases of cell metabolism occur upon elicitation. The phases can be distinguished as biochemical changes (phase 1), the alteration of gene expression (phase 2) and the switching on of the defense response/ metabolite production (phase 3 ). The present study also confirms the existence of such a pattern of different phases in the $C$. roseus cells metabolism upon elicitation.

Although PCA discriminated between groups, the distinction between metabolites that were really associated with SA elicitation was not yet clear because another factor, developmental stage $(0-72 \mathrm{~h}$ in this study), also largely influenced the metabolic change of the $C$. roseus cell line. To deconvolute the metabolic alteration caused by SA-treatment, a supervised multivariate data analysis, partial least square-discriminant analysis (PLS-DA) in which two classes (control and SA-treatment) were used for Y-matrix combined with X-matrix of NMR data was applied to the NMR data set. As shown in Fig. 3 all the samples employed in this study were clearly separated by SA treatment. In the loading plot the NMR signals associated with SA-treatment are sorted

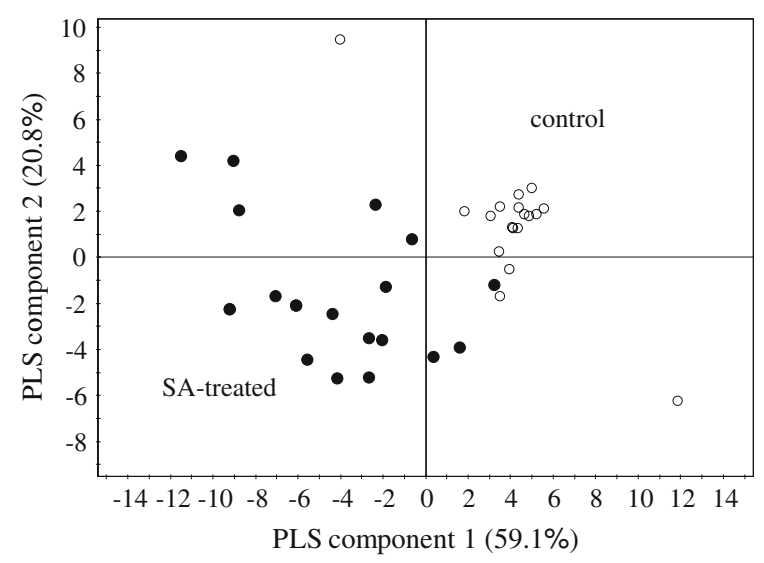

Fig. 3 Score plot of partial least square-discriminant analysis of projected one dimensional J-resolved data of Catharanthus roseus cells. Open circle: control, filled circle: SA-treated cell lines 
out. In the SA-treated cell lines gentisic acid glucoside, fumaric acid, and phenylalanine were shown to be largely increased throughout the experimental time (from 0 to $72 \mathrm{~h}$ after treatment).

Fumaric acid was present at low levels at $0-24 \mathrm{~h}$ in both the control and treated cells (Fig. 3) but, while a slight increase was observed from 48 to $72 \mathrm{~h}$ in control cells, a significant increase occurred in elicited cells in the same period, probably as a storage product due to a down-regulation of the Krebs cycle. Fumaric acid is an intermediate in the Krebs cycle that can be converted into malic acid, oxaloacetate and subsequently to phosphoenolpyruvate (PEP), a precursor of shikimate and chorismate. Some enzymes in the Krebs cycle are down-regulated if the level of energy (ATP) in the cell is already high, thus no excess oxaloacetate would be available to enter the Krebs cycle (Berg et al. 2002) resulting consequently in a high concentration of fumaric acid .

Phenylalanine was detected in both control and SA-treated cells. In the SA-treated cells the minimum level of phenylalanine occurred at $6 \mathrm{~h}$ after treatment, increasing again (16-fold) to reach the highest level at $72 \mathrm{~h}$.

The almost total conversion of fed SA into gentisic acid glucoside by $C$. roseus suspension cells has been reported (Shimoda et al. 2002). However, in our experiments the levels of gentisic acid glucoside in the cells represented only $10 \%$ of the fed SA. As the media were not analyzed, we cannot exclude the possibility that the amounts of benzoic acid derivatives present in the media would complete the mass balance of the SA bioconversion. These results do not provide sufficient evidence to conclude that gentisic acid glucoside is formed from SA though, considering the results of Shimoda et al. (2002), it could be expected that this is the case, being produced by oxidation of SA followed by glucosylation. The signals of gentisic acid glucoside appeared weakly at $24 \mathrm{~h}$ and strongly increased in intensity at 48 and $72 \mathrm{~h}$.

Although PLS-DA showed a clear association between the metabolites and groups, many primary metabolites including sugars and amino acids were not clearly detected in PLS-DA because they showed transient behavior during the experimental conditions between 0 and $72 \mathrm{~h}$ after treatment. Dynamic levels of sugars, aliphatic amino acids and organic acids are shown in Fig. 4. For instance, in the case of sugars (glucose and sucrose) the SA-treated cells showed the highest levels at $0 \mathrm{~h}$ decreasing subsequently to zero after $72 \mathrm{~h}$. This might be due to the fact that in the first few minutes after the addition of SA $(0 \mathrm{~h})$, the soluble sugar pool in the cells increased probably to provide precursors and energy (ATP) for cells response to elicitation. However, the control cells showed an increased level of sugars at $6 \mathrm{~h}$ as compared to $0 \mathrm{~h}$ which decreased also to zero after $72 \mathrm{~h}$. Increased levels of sugars were also reported to occur for example in $C$. roseus intact plants infected by phytoplasma (Choi et al. 2004) or potato leaves and tubers under different stress conditions (Świędrych et al. 2004). The latter group showed that increased levels of glucose, fructose and sucrose were a result of mobilization of starch initiated by catecholamines under stress conditions. Besides, glucose is also necessary for the detoxification of compounds by glycosylation (reviewed by Yamane et al. 2002). Depletion of sugars was found in 48-72 h control cells and almost no sugar was left in the $C$. roseus A12A2 cells 7 days after subculturing. This may explain the relatively stable fresh-weight of $C$. roseus cells observed after the fifth day of subculturing (Budi Muljono et al. 2002) when the cell culture growth stopped.

In the case of other metabolites, such as amino acids, maximum levels of valine, alanine, aspartic acid and fumaric acid were detected at $6 \mathrm{~h}$ after elicitation, whilst leucine and isoleucine showed minimum levels at that same time. In this initial $6 \mathrm{~h}$ period, the pyruvate pool might increase through glycolysis, the Krebs cycle and the catabolism of leucine and isoleucine, generating an increase in the valine, alanine, aspartic acid and fumaric acid levels. At $12 \mathrm{~h}$ after elicitation, the levels of the amino acids and organic acids (leucine, isoleucine, valine, threonine, aspartic acid and fumaric acid except glutamic acid and alanine) were back again to the initial levels, but subsequently increased again to reach another maximum at 48-72 h. This could imply that from 12 to $48 \mathrm{~h}$, the pyruvate pool probably increased again in order to provide the precursors required for the synthesis of secondary metabolites.

Glutamate level in control cells remained constant throughout all the experiment, but decreased slowly in elicited cells (Fig. 3e). Glutamate is necessary for ammonia $\left(\mathrm{NH}_{3}\right)$ assimilation to prevent the build-up in the cell of toxic ammonia, which is produced by the reduction of nitrate $\left(\mathrm{NO}_{3}{ }^{-}\right)$, nitrogen fixation or 
Fig. 4 Time course $(0-72 \mathrm{~h})$ of the relative levels of sugars, aliphatic amino acids, organic acids in the control and

SA-treated cells of Catharanthus roseus determined by a comparison of the peak-intensity of the compounds to that of 3-(trimethylsilyl)propionic acid-2,2,3,3- $d_{4}$ acid sodium salt $(100 \%)$
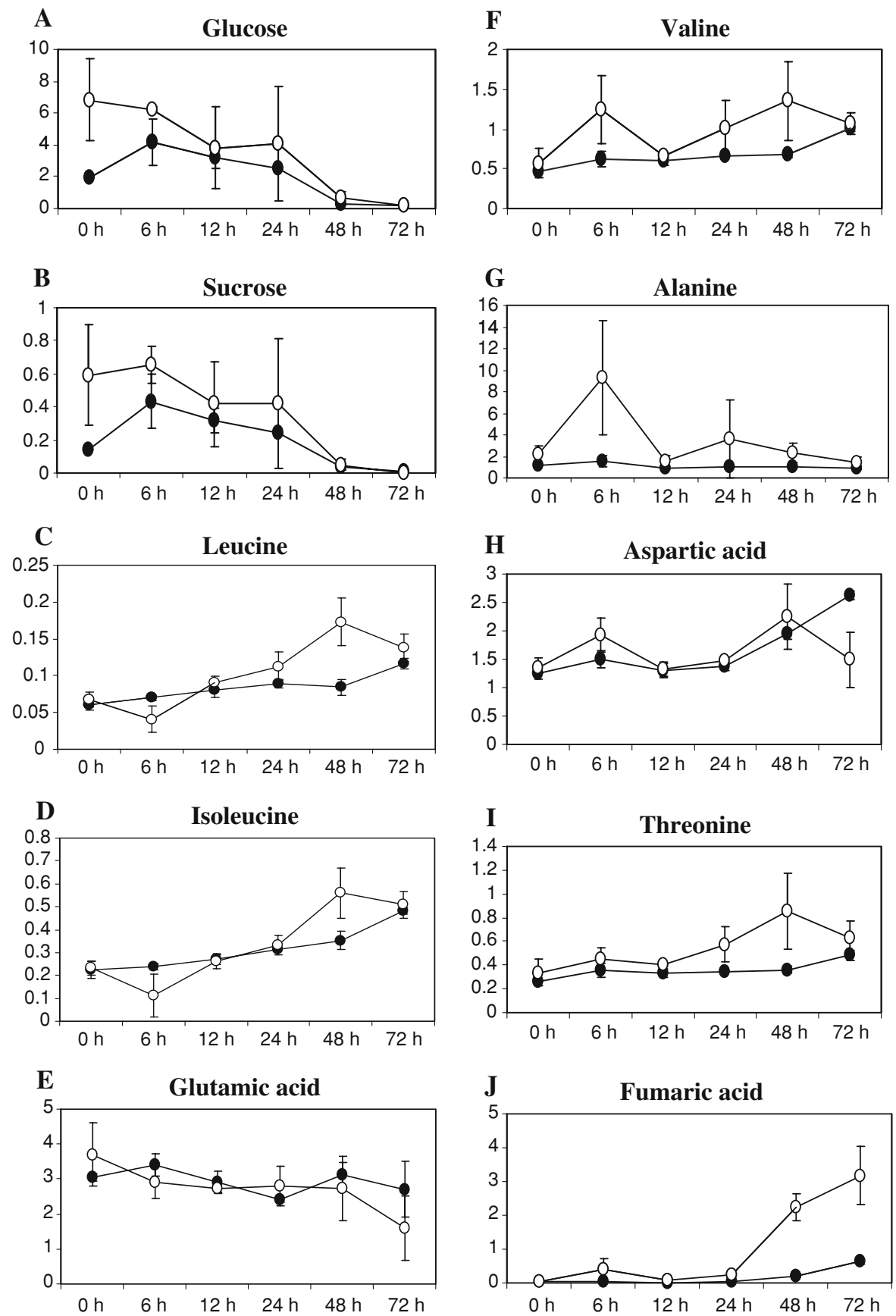

from the catabolism of other amino acids. Ammonia assimilation by glutamate leads to glutamine, which can be transaminated to obtain glutamate again when the amide amino group of glutamine is transferred to other compounds. The enzymes responsible for this, (glutamine synthetase, EC 6.3.1.2 and glutamate synthase EC 1.4.1.13 or EC 1.4.7.1) are involved in the glutamate synthase cycle. Glutamate can also be converted to proline and arginine.

In summary, application of NMR spectroscopy in combination with PCA and PLS-DA on the extracts of C. roseus suspension cells clearly revealed an alteredmetabolite profiles of SA-treated cells as compared to control cells during a period of $0-72 \mathrm{~h}$. SA signals 
already appeared weakly at $0 \mathrm{~h}$ and were detected clearly at 6-24 h. Sugars (glucose and sucrose) were found in increased-levels at $0-24 \mathrm{~h}$ in the SA-treated cells compared to the control cells (highest levels at $0 \mathrm{~h}$ ), but depletion of sugars occurred at $48-72 \mathrm{~h}$ in both control- and SA-treated cells. The levels of some aliphatic amino acids and organic acids in the SA-treated cells showed two maxima at $6 \mathrm{~h}$ and $48 \mathrm{~h}$. The fed SA disappeared after $48 \mathrm{~h}$, but at the same time gentisic acid glucose (2,5-DHBAG) signals appeared. Overall the metabolic response exhibited two phases, an immediate change of the metabolome followed by a partly return to normal conditions and a subsequent second major change in the metabolome. The first phase could probably represent an immediate biochemical response, followed by a second response at gene level.

Open Access This article is distributed under the terms of the Creative Commons Attribution Noncommercial License which permits any noncommercial use, distribution, and reproduction in any medium, provided the original author(s) and source are credited.

\section{References}

Berg JM, Tymoczko JL, Stryer L, Clarke ND (2002) Biochemistry, 5th edn. W. H. Freeman and Company, New York

Budi Muljono RA, Scheffer JJC, Verpoorte R (2002) Isochorismate is an intermediate in 2,2-dihydroxybenzoic acid biosynthesis in Catharanthus roseus cell cultures. Plant Physiol Biochem 40:231-234

Choi YH, Tapias EC, Kim HK, Lefeber AWM, Erkelens C, Verhoeven JTJ, Brzin J, Zel J, Verpoorte R (2004) Metabolic discrimination of Catharanthus roseus leaves infected by phytoplasma using ${ }^{1} \mathrm{H}-\mathrm{NMR}$ spectroscopy and multivariate data analysis. Plant Physiol 135:2398-2410

Choi YH, Kim HK, Linthorst HJM, Hollander JG, Lefeber AWM, Erkelens C, Nuzillard J-M, Verpoorte R (2006) NMR metabolomics to revisit the tobacco mosaic virus infection in Nicotiana tabacum leaves. J Nat Prod 69: $742-748$

Fraccaroli M, Nicoletti S, Maltese F, Choi YH, Guzzo F, Levi M, Verpoorte R (2008) Preanalytical method for metabolic profiling of plant cell cultures of Passiflora garckei. Biotechnol Lett 30:2031-2036

Moreno PRH, Van der Heijden R, Verpoorte R (1994) Elicitormediated induction of isochorismate synthase and accumulation of 2, 3-dihydroxybenzoic acid in Catharanthus roseus suspension and shoot cultures. Plant Cell Rep 14:188-191

Moreno PRH, Poulsen C, Van der Heijden R, Verpoorte R (1996) Effects of elicitation on different metabolic pathways in Catharanthus roseus (L.) G.Don cell suspension cultures. Enz Microb Technol 18:99-107

Murashige T, Skoog F (1962) A revised medium for rapid growth and bioassays with tobacco cultures. Physiol Plant 15:473-497

Mustafa NR, Verpoorte R (2005) Chorismate derived C6C1 compounds in plants. Planta 222:1-5

Mustafa NR, Verpoorte R (2007) Phenolic compounds in Catharanthus roseus. Phytochem Rev 6:243-258

Mustafa NR, Kim HK, Choi YH, Erkelens C, Lefeber AWM, Spijksma G, Van der Heijden R, Verpoorte R (2009) Biosynthesis of salicylic acid in fungus elicited Catharanthus roseus cells. Phytochemistry 70:532-539

Pasquali G, Goddijn OJM, de Waal A, Verpoorte R, Schilperoort RA, Hoge JHC, Memelink J (1992) Coordinated regulation of two indole alkaloid biosynthetic genes from Catharanthus roseus by auxin and elicitors. Plant Mol Biol 18:1121-1131

Ryals JA, Neuenschwander UH, Willits MG, Molina A, Steiner HY, Hunt MD (1996) Systemic acquired resistance. Plant Cell 8:1809-1819

Shimoda K, Yamane S-Y, Hirakawa H, Ohta S, Hirata T (2002) Biotransformation of phenolic compounds by the cultured cells of Catharanthus roseus. J Mol Catal B 16:275-281

Suhartono L, Van Iren F, De Winter W, Roytrakul S, Choi YH, Verpoorte R (2005) Metabolic comparison of cryopreserved and normal cells from Tabernaemontana divaricata suspension cultures. Plant Cell Tiss Org Cult 83: 59-66

Świędrych A, Lorenc-Kukula K, Skirycz A, Szopa J (2004) The catecholamine biosynthesis route in potato is affected by stress. Plant Physiol Biochem 39:595-602

Van der Fits L, Memelink J (2001) The jasmonate-inducible AP2/ERF-domain transcription factor ORCA3 activates gene expression via interaction with a jasmonate-responsive promoter element. Plant J 25:43-53

Verberne MC, Verpoorte R, Bol JF, Mercado-Blanco J, Linthorst HJM (2000) Overproduction of salicylic acid in plants by bacterial transgenes enhances pathogen resistance. Nat Biotechnol 18:779-783

Viant MR (2003) Improved methods for the acquisition and interpretation of NMR metabolomic data. Biochem Biophys Res Comm 310:943-948

Yamane S-Y, Shimoda K, Wataname K, Hirata T (2002) Purification and characterization of gentisic acid glucosyltransferase from the cultured cells of Catharanthus rosues. J Mol Catal B 17:59-63 